\title{
O ENLACE ENTRE TEORIA POLIITICA MUNICIPAL E RELIGIÃO NO MUNDO IBÉRICO DA BAIXA IDADE MÉDIA AO ALVORECER DA MODERNIDADE: O CASO DOS ALMOTACÉS
}

THIAGO ENES*

Resumo: Através da análise da atuação dos juízes almotacés nas cidades Ibéricas pretendemos demonstrar que alguns preceitos migraram dos dogmas religiosos da Igreja Católica para a teoria política municipal posta em prática nas cidades de Portugal e Espanha durante a Idade Média. Para tanto, analisaremos a linha de filiação do ofício, que sofreu influências gregas, romanas e ainda esteve vinculado às mais básicas necessidades locais, até alcançarem à Modernidade e chegarem, com grande fôlego, aos domínios ultramarinos desses reinos.

Palavras-chave: Almotaçaria, almotacé, administração municipal Ibérica.

The link between local Iberian political theory and religion from the Late Middle Age to the Modern Age: the almotacés study case.

Abstract: Through the analysis on the performance of the Almotacés in the Iberian cities we intend to demonstrate that some rules migrated from the religious dogmas of the Catholic Church to the municipal political theory that were in pratice in the cities of Portugal and Spain during the Middle Ages. We analyze the line of affiliation of the position, which was influenced by ancient Greek, Roman and also by the most basic local needs, until reaching Modernity and the overseas dominions of these two kingdoms.

Keywords: Almotaçaria, almotacé, Iberian local adminsitration.

O estudo da Era Moderna e as reflexões acerca do advento do novo mundo firmaram-se como objetos tão interessantes quanto diversos diante do olhar dos historiadores. São testemunhos dessa renovação a nova dimensão dos construtos políticos e as formas de poder constituídas pelas monarquias Ibéricas. Várias são as investigações que se voltaram para as instituições e concepções político-administrativas que regeram o cotidiano burocrático, balizando e definindo o viver mesmo nas mais longínquas regiões do vasto espaço para onde esta malha governativa foi posta em prática. Para o caso Português, mais recentemente, as Câmaras Municipais assumiram papel fundamental no centro de tórrido debate. Sua importância é sobejamente demonstrada por terem sido órgãos fundamentais de representação das demandas e dos interesses dos governados, ${ }^{1}$ verdadeiros pilares da sociedade portuguesa nos quatro cantos do mundo e elementos de unidade e continuidade entre reino e seus domínios.

\footnotetext{
* Doutorando em História na Universidade Federal Fluminense (UFF).

${ }^{1}$ A respeito dessa relação entre espaço social e poder ver: Bourdieu, 1989.
} 
(Bicalho, 1998, p. 251) ${ }^{2}$ Assim como as Companhias de Ordenanças e as Paróquias, as instituições camarárias firmaram-se como marcas do modo de governo daquela coroa (Monteiro, 1983, p. 304-309). Estiveram presentes com absoluta uniformidade e, segundo Charles Boxer, um dos maiores estudiosos da estrutura política promovida pela expansão ultramarina, os Senados e seus "homens bons" foram poderosos e eficientes instrumentos dos quais Portugal lançou mão para manter unidos os laços entre as suas diferentes possessões, assim como as irmandades de caridade e as confrarias laicas (Boxer, 2002).

No horizonte das pesquisas dessa natureza, se é certo que o estudo das Câmaras é refinamento teórico recente e tem ganhado corpo, fruto do interesse de pesquisadores, sobretudo portugueses ${ }^{3}$, pelas municipalidades, o mesmo não se pode dizer das investigações sobre os ofícios municipais e suas esferas de atuação nas vilas e cidades de Ibéricas. Nas últimas duas décadas aumentou o interesse pelos temas do poder municipal, delineando novas perspectivas historiográficas e redefinindo o papel das Câmaras no Antigo Regime, como contrapartida do poder político do topo. No entanto, ainda faltam estudos que privilegiem os instrumentos de comunicação entre periferia e centro, e que revelem como se articulavam o poder municipal e os "outros tipos de autoridade e sociabilidade locais". (Wehling e Wehling, 2000, p.303) As estratégias de poder e as tarefas dos agentes do governo municipal são temas que permanecem pouco visitados, ou mesmo subjugados pela historiografia, que se ateve, quase que exclusivamente, aos Senados, aos ofícios de carreira ${ }^{4}$ e suas composições, alheia à

\footnotetext{
${ }^{2}$ Há que se destacar o trabalho pioneiro Charles Boxer sobre a importância das instituições como as Câmaras e as Misericórdias, que influenciaram John Russell Wood, seu orientando de doutorado, e Eulália Maria Lahmeyer Lobo, sua grande amiga no Brasil. Ver: (Boxer, 2002; Lobo, 1975, Russel-Wood, 1981).

3 Para José Viriato Capela, pesquisador das municipalidades no Portugal moderno, para a renovação da história municipal concorreram, poderosamente, novos domínios de investigação histórica. Os aspectos financeiros e da contabilidade municipal, os mercados e a formação dos preços, o funcionamento das almotaçarias, o desenvolvimento da história institucional, da mobilidade social e das elites foram decisivos para que as municipalidades assumissem, definitivamente, suma importância na base da historiografia econômica e social europeia pós-guerra. Veja: (Capela, 2005. p. 42).

${ }^{4}$ A maior parte da historiografia trata dos ofícios municipais de forma descurada, afirmando serem todos os funcionários municipais agentes diretos das Câmaras. Cabe ressaltar que, das fronteiras da região platina à remota península de Macau, as Câmaras portuguesas tinham apenas dois tipos de oficiais em exercício. Os cargos eletivos, aos quais era facultado o direito a voto eram compostos por dois juízes ordinários, não necessariamente versados em leis, de dois a quatro vereadores e um procurador. Esses cargos compunham o que, efetivamente, se entende por oficial camarário. Todos os demais cargos não pertenciam diretamente à hierarquia funcional da realeza, embora mantivessem nítidas e óbvias ligações com o poder, seja ele local ou real. Alguns deles eram remunerados por meio de salá-
} 
tessitura administrativa representada pelos pequenos poderes, embora tais ocupações sejam capazes de elucidar inúmeras questões relativas ao cotidiano urbano e político.

Ainda são enuviadas as informações a respeito do corpo de funcionários e das práticas das instituições administrativas portuguesas, principalmente quando se trata dos ofícios considerados menores na hierarquia de mando. À título de exemplo, a historiografia pouco esclarece sobre alcaides, meirinhos, juízes de vintena, quadrilheiros, escreventes, secretários, vereadores de correição, inspeção, avaliadores urbanos e jurados. ${ }^{5}$ Mesmo em Portugal, é difícil encontrar fontes sobre a atuação dos juízes e funcionários locais, pois a própria legislação recomendava a esses magistrados que sentenciassem verbalmente, sem apelação, agravo ou processo ${ }^{6}$, acrescido do fato de que, especialmente no ultramar, havia grande número de oficiais iletrados, assessorados por indivíduos letrados.

Ao darmos continuidade ao estudo da teoria política Ibérica, torna-se imperioso refletirmos sobre como o corpo de leis e demais códigos de posturas foram gestados até serem levados à cabo pelos monarcas europeus. Para tanto, propomos um breve ensaio que contemple, de modo particular, a atuação do direito de almotaçaria e seus oficiais, os almotacés, cargo do poder local que vem sendo pouco visitado, ou mesmo subjugado por grande parte das investigações. Ao nos lançarmos em tal empreitada acreditamos que não só o estudo pontual do código de leis e aditamentos políticos promulgados seja profícuo, mas também, o conhecimento sobre o cotidiano dos próprios sujeitos históricos, súditos de El-Rei, governados por estas posturas, principalmente nas esferas urbanas, vilas e cidades.

A genealogia do ofício de almotacé aponta para uma longa linha de filiação que se inicia no agoranomo grego, passando edil curul romano e chegando no muhtasib islâmico, posteriormente cristão. (Pereira, 2001, p. 372) ${ }^{7}$ Durante o chamado período clássico grego a magistratura ateniense contava com o agoranomo (ou agoránome)

rios e outros obtinham ganhos proporcionais às atividades exercidas por meio de multas e apreensões de mercadorias confiscadas.

${ }^{5}$ Pesquisa recente investigou a atuação de um desses cargos, os juízes de vintena, no Termo de Mariana. Ver: Pires, 2005.

${ }^{6}$ ORDENAÇÕES Filipinas. Livro 1, Título LXV. p. 144.

${ }^{7}$ Ainda segundo Luís Filipe Thomaz a tessitura de reconquista da península Ibérica não foi única, tendo em vista que o processo portucalês é unilateral, em dissonância com o processo espanhol, extremamente fragmentário, que deu origem às atuais nações e especificidades regionais, como ocorre na Galícia, Castela, Catalunha etc. Ver: Thomaz, 1998. 
para manter a boa ordem na praça do mercado. Este funcionário inspecionava mercadorias, evitando fraudes e falsificações, julgava os pleitos que se suscitavam entre vendedores e compradores, examinava pesos e medidas (auxiliado por um ajudante denominado metronomos) e, finalmente, se ocupava da vigilância de templos e de cobrar certos impostos de estrangeiros. Algumas pesquisas afirmam que todas as cidades, incluindo as comunidades nas ilhas de Tasos, Quios, Lesbos e Rodes contavam apenas com um agoranomo, cargo inicialmente ocupado pelo período de um ano. Somente Atenas e Halicarnasso contavam com mais de um magistrado que, aos poucos, passou a ter sua duração diminuída (Montsserat, 2003, p.49). Já outros autores advogam que havia cinco agoranomos resguardando Atenas, e outros cinco responsáveis pelo porto de Pireo (Carrera, 1828, p. 44). Já a palavra edil, do latim aedilis designa uma magistratura surgida, acredita-se, pelos idos de 494 a.C., durante a chamada República romana. Quando foi criado, também conhecido como edil plebeu, o cargo tinha por função proteger e zelar pelos direitos da plebe, incluindo tarefas vinculadas às celebrações e rituais de veneração à Ceres, considerada a deusa da lavoura, uma vez que este extrato social romano dominava o comércio de cereais. Posteriormente surgiu a figura do edil curul, função que passou a ser exercida tanto por plebeus quanto por patrícios. Segundo Tito Lívio, os edis curuis eram nomeados aos pares pelas Assembleias romanas e eram encarregados do fornecimento de cereais, abastecimento de água, supervisão dos mercados, preços e qualidade dos produtos, com autoridade para julgar ações penais correlatas. Gozavam ainda de jurisdição sobre questões sanitárias e ficavam de zelar pelos edifícios públicos. Sempre supervisionado por um pretor urbano, o edil curul ainda organizava certos jogos que ocorriam em Roma, financiados, em parte, com as multas impostas aos que descumpriam as disposições mencionadas. ${ }^{8}$

Mesmo reconhecendo no muhtasib islâmico a sobrevivência dos agoranomos gregos (ou mesmo bizantinos) ${ }^{9}$ e do edil curul romano ${ }^{10}$ e ainda que essas linhagens sejam fundamentais para se compreender que as funções do ofício, que por hora in-

\footnotetext{
${ }^{8}$ Por suas funções e posicionamento na sociedade romana, os edis contavam com certos privilégios. Poderiam sentar-se na sella curulis, vestirem-se com a toga praetexta, vestimenta utilizada em grandes ocasiões, eram facultados ao lus Imagium, direito de guardar em casa as estátuas dos antepassados ilustres e ainda poderiam promulgar editos, lus Edicendi (Rubio, 2012; Hachette, 1842, p. 540).

9 Muitos estudos reconhecem no muhtasib a sobrevivência dos agoránomos bizantinos. Ver: Schacht, 1950, p. 202.

${ }^{10} \mathrm{O}$ próprio comentarista das Ordenações Filipinas sublinha a ligação dos almotacés com o edil curul romano. ORDENAÇÕES Filipinas. Livro 1, Título LXVIII. p. 157.
} 
vestigamos, nascem com a própria invenção das cidades, há quem nos advirta que tais genealogias mais confundem do que efetivamente esclarecem. Fundamental seria, então, passarmos ao seu exame sob a ótica da continuidade, ou sua possível ruptura, considerando a administração das cidades portuguesas pré e pós-conquista (Pereira, 2001, p. 157). ${ }^{11}$

Na edição de 1870 o jurista Cândido Mendes de Almeida afirma em nota às Ordenações Filipinas que o almotacé era um "antigo funcionário régio de eleição das Câmaras que tinha a seu cargo cuidar da igualdade dos pesos e medidas, taxar e às vezes distribuir mantimentos e outros gêneros que se compram e se vendem à miúde." Esclarece, ainda, que a expressão é proveniente do árabe al-mohtacel, que deriva do verbo hoçaba, que significa contar, calcular. ${ }^{12}$ Rui de Abreu Torres, em seu Dicionário de História de Portugal, afirma que a almotaçaria é um ofício do direito municipal que evitava que os rendeiros fizessem avença com as partes no pescado levado à praça, presidiam um tribunal de pequenos delitos de venda, constituindo a polícia do comércio interno dos Concelhos ${ }^{13}$, assemelhando-se aos edis romanos. Torres acrescenta que os almotacés tinham alçada até 600 réis para julgar os feitos em matéria de suas atribuições, em processo sumário. (Torres, 1992, p. 121). De forma bastante sucinta, o jesuíta D. Raphael Bluteau explicita em seu Vocabulário Portuguêz e Latino, publicado em princípios do século XVIII, que o termo e o ofício do almotacé derivam do "antigo arábico Al \& Musabocin", que é o mesmo que moderador dos preços em coisas de comer. Destaca ainda que em alguns Concelhos atuava o almotacé de limpeza, que segundo ele é um curador urbano ou urbice munditie, além de uma interessante variação, o ofício de almotacé da fruta (Bluteau, 1728).

Especificamente na península Ibérica, não houve uma descontinuidade urbana, como de fato aponta Oliveira Marques, e muitas instituições foram herdadas das cidades islâmicas; diferentemente da região norte da Europa, onde a descontinuidade foi

\footnotetext{
${ }^{11}$ Segundo Luís Felipe Thomaz a tessitura de reconquista da península não foi única, tendo em vista que o processo portucalês é unilateral, dissonância com o processo espanhol, extremamente fragmentário, que deu origem às atuais nações e especificidades regionais, como ocorre na Galícia, Castela, Catalunha, País Basco etc. Ver: Thomaz, 1998.

12 ORDENAÇÕES Filipinas. Livro I. Título XVIII. p. 46.

${ }^{13}$ Concelhos, termos que aparecem nos diplomas a partir do século XIII é uma expressão latina que exprime os órgãos colegiados que, organizados e constituídos pela Coroa, foram os elementos essenciais da administração da monarquia em Portugal e Espanha. Designa ainda comunidades vicinais constituídas em território, cujos moradores são dotados de autonomia administrativa.
} 
maior e pode-se falar até mesmo em certa invenção das unidades de controle da cidade (Pereira, 2001, p. 371). Cabe ressaltar que esta herança islâmica não é estática, uma vez que a almotaçaria e quase toda a esfera urbana foram incorporadas e modificadas pelos senhores cristãos.

Nestas cidades muçulmanas não havia autonomia administrativa e o império Omíada era gerido por uma cadeia de cidades que estavam diretamente submetidas à autoridade central, representada por seus delegados regionais e locais. Ocorre que os povos muçulmanos utilizaram-se fartamente de uma série de estruturas administrativas que foram reproduzidas a partir do império Bizantino, do qual haviam se apossado de parte do território; e foram justamente estes oméias os empreendedores da conquista da península Ibérica, amplamente apoiados nos exércitos de berberes convertidos ao islã (Pereira, 2001, p. 372).

Em árabe, a expressão mutahsib designava o titular da hisba, aquele responsável pela sua gestão e efetiva implementação no seio citadino. Nos núcleos urbanos muçulmanos a hisba era a instituição incumbida da adequada verificação de pesos e medidas, inspeção do estado dos gêneros alimentícios apresentados aos mercados, e por zelar pela equidade das transações comerciais cotidianas. À hisba ainda cabiam aspectos referentes à sanidade urbana e à entidade física da cidade, ficando o mutahsib responsável pela manutenção das muralhas, reparação das vias públicas e pelo controle das construções dispostas pela urbe, de modo que os moradores não infringissem uma série de normas vigentes (Colom, 1953, p. 527). Notamos, portanto, a proximidade do instituto da hisba islâmica medieval com aquilo que mais tarde seria denominado almotaçaria.

Mesmo apresentando algumas pequenas alterações, o cargo foi incorporado nas tradições citadinas dos reinos da península Ibérica. Foram preservados os termos almotacé, para Portugal, almotacém em Castela e mustaçaf nos reinos orientais da península e nos Baleares. Após a reconquista, também foi mantida a centralização política de antes, manifestada na forma de prover o cargo, pois os novos reis cristãos continuaram a resguardar para si a nomeação do ocupante do ofício, através dos alcaides, agentes de controle local, evitando assim a perda do controle administrativo das cidades sob a sua jurisdição (Caetano, 1991, p. 16).

Aos poucos, e de forma muito heterogênea nos diversos pontos da península 
Ibérica, a almotaçaria foi deixando de ser um ofício régio para se tornar uma função concelhia, isto é, de eleição e de responsabilidade da municipalidade. No caso de Portugal, as primeiras Câmaras que receberam o foral que tornava a almotaçaria um cargo de eleição regional foram as de Lisboa, Coimbra e Santarém, privilégio concedido por D. Afonso Henriques em 1179 (Pereira, 2001, p. 373). Corroborando a falta de uniformidade com que o ofício da almotaçaria foi aos poucos sendo incorporado pela municipalidade, variando de reino a reino, temos o exemplo de Barcelona, onde até meados do século XV a escolha do mustaçaf era feita através de uma lista tríplice ou quádrupla apresentada pelos "homens bons" ao soberano de Aragão, a quem realmente competia a decisão final.

Era prática comum durante a Idade Média que cidades menores ou vizinhas adotassem legislações parecidas ou baseadas nos forais de núcleos urbanos mais desenvolvidos, e isso fez com que os privilégios concedidos às cidades mais destacadas se estendessem também a outros municípios que implementavam administração semeIhante. Deste modo, não tardou para que cidades ao sul do rio Tejo, que adotavam forais que seguiam os de Coimbra, Ávila e até mesmo Salamanca, obtivessem o privilégio e a responsabilidade da eleição dos almotacés que atuariam em seus espaços urbanos. A mesma situação ocorreu na Beira, Estremadura e Alentejo, de modo que, com a conquista do Algarve tempos depois, onde a maioria das cidades adotavam forais semelhantes ao de Lisboa, após o século XIII, tornou-se um padrão que o ofício fosse somente de nomeação concelhia (Pereira, 2001, p. 373).

Com esta crescente eleição local, a escolha que passava das mãos do soberano para a municipalidade representou invariavelmente uma diminuição ou atrofia da esfera de atuação reservada ao cargo, que ficava sendo nomeado por vereadores e a eles diretamente submetido. Várias foram as atribuições anteriormente da alçada do almotacé que acabaram por se tornar responsabilidade de outros vereadores ou oficiais das Câmaras e Cabildos. Todavia, mesmo sendo nomeados pelas municipalidades, as atribuições básicas dos almotacés perduraram e, de fato, foram mantidas em todos os territórios portugueses e espanhóis de ultramar, assim como o termo a que eram designados. $^{14}$

\footnotetext{
${ }^{14}$ Nas notas das Ordenações Filipinas Candido Mendes de Almeida afirma que até o século XIX, período em que houve reforma das instituições governativas, de justiça e de direito, o termo permaneceu i-
} 
Na Idade Média o almotacé era um magistrado local que tinha como função precípua assegurar o abastecimento e policiamento do mercado urbano, controlando a produção engendrada em âmbito municipal, zelando pela limpeza e manutenção das cidades e gerindo causas relacionadas à ocupação do espaço urbano. Ângela Beirante tenta circunscrever algumas suas atividades ao afirmar que eles estavam investidos de autoridade jurisdicional e até mesmo legislativa, que permitia aplicar sansões aos infratores e, em certos casos, participar da elaboração das posturas municipais (Beirante, 1995). Esses oficiais deveriam julgar processos sumários e infrações sobre as matérias de sua competência, podendo as penas reverterem-se sob a tríplice forma de coimas $^{15}$, prisões e açoites. Dentre os constrangimentos públicos previstos ainda figuravam os discursos moralizantes, degredos nos casos considerados mais graves ou mesmo a condenação do réu ao patíbulo, em situações extremas ou de reincidência.

O bom oficial era aquele que observava atentamente se a vila estava bem provida de carniceiros, almocreves, padeiros, tavernas, regateiras ${ }^{16}$, e demais comerciantes, governando juntamente com seus alvazis (juízes) e demais vereadores, procuradores e vintenas componentes do Concelho. ${ }^{17}$ Deveriam prestar contas ao juízo da almotaçaria todos aqueles que de algum modo se utilizavam de pesos, balanças ou medidas para o seu trabalho. Assim, não só a comercialização de mantimentos pertencia à sua alçada, mas os negociantes de tecidos e também sapateiros, alfaiates, carpinteiros e ferradores deveriam prestar contas de seu oficio através do pagamento de impostos arrecadados pelos almotacés. Lançando mão das coimas e demais constrangimentos este oficial deveria estar acompanhado de um meirinho em suas correições pelas vilas, ou de um homem juramentado que o auxiliasse a agir com prudência e sobriedade em

dêntico. Depois desta reformulação houve certa latinização do termo e o oficial, que ainda manteve resguardadas grande parte das suas atribuições, passou a ser chamado simplesmente de fiscal. Ver: ORDENAÇÕES Filipinas. Livro 1. Título LXVIII. p. 157.

${ }^{15}$ As coimas eram multas, penalidades pecuniárias impostas aos desviantes das posturas municipais.

${ }^{16}$ Carniceiro: "aquele que decepa a rez, a nata, a estola e a limpa dos debulhos. É obrigado a ter pesos de arroba e meia arroba e arretéis, e afilar os pesos a cada dois meses, e pode comprar o gado que for necessário para o talho, sem outra licença." Almocreve: "levam bestas de carga de uma parte à outra." Regateira: "mulher que compra pescado, hortaliça, fruta e outros mantimentos para os tornar a vender com algum emolumento" (Bluteau, 1728).

${ }^{17}$ Em árabe, alvazil faz referência a um ajudante, aquele que ajuda a carregar pesos. Segundo Luís Vidigal os alvazis não eram delegados régios, mas tinham os seus lugares assegurados por aqueles que, pelo seu estatuto, tinham reconhecimento local, com função eminentemente auto-reguladora e honorária. (Vidigal, 1993. p. 109). 
suas deliberações. ${ }^{18}$ Via de regra, as coimas eram arrendadas a terceiros, que tinham a sua atividade fiscalizada de perto pelos oficiais do Concelho. O braço direito dos almotacés eram os escrivães da almotaçaria, que deveriam se fazer presentes em audiências e registrar as penas pecuniárias. ${ }^{19}$

No último quartel do século XV o cargo já era considerado um dos principais da municipalidade. Mais proeminentes eram os almotacés atuantes na corte. Em tempos mais recuados Portugal contava com a presença de dois almotacés ditos mores. Segundo a definição de Bluteau, o almotacé mor, Aedilis maximus, teria como função "prover o lugar onde estiver a corte de mantimentos, além de tocar-lhe mandar limpar as ruas, refazer caminhos, pontes e calçadas." Arremata afirmando que o ofício de almotacé mor da corte de Lisboa andava na família dos Farias (Bluteau, 1728). O almotacé mor deveria ser cavaleiro e eleito pelo Concelho. Além de manter a corte abastada de mantimentos, dos quais se destacavam a carne, o pão, o vinho, o azeite, o pescado e a palha, competia ao almotacé mor zelar pela venda do vinho no período de relego. ${ }^{20}$ Também ficava a seu cargo a mediação entre a corte e os ditos regatães ou vendeiros, uma vez que ele era o responsável pela circulação desses negociantes pela corte e resguardava para si a concessão da devida licença para deixá-la.

Nos núcleos urbanos portugueses e espanhóis da Idade Média, a expressão almotaçar fazia referência ao ato efetivo de manter, administrar, gerir, ou seja, veer a cidade ou urbe em seu sentido mais lato. Apenas mais tarde a palavra começou a ser utilizada pelos oficiais das Câmaras Municipais e dos Cabildos como algo relacionado ao abastecimento e ao controle das atividades comerciais, e no século XIX, quando o cargo foi extinto, ao menos no caso da legislação portuguesa, expressava tão somente o tabelamento e o controle dos preços das mercadorias.

Seja como for, o instituto da almotaçaria, desde sua mais tenra origem, esteve intrinsecamente ligado àquilo que se entendia como urbano e, paralelamente, também esteve vinculado a uma estreita noção de igualdade e, por que não dizer, de jus-

\footnotetext{
${ }^{18} \mathrm{O}$ ofício de meirinho, criado em Portugal pelo regimento de 1332, era o responsável imediato pela aplicação das possíveis sanções previstas em situações de descumprimento do direito de almotaçaria, atuando como uma espécie de agente policial, se escusado o anacronismo.

${ }^{19}$ Sobre as atribuições do escrivão da almotaçaria, veja: (Salgado, 1986, p. 142).

${ }^{20}$ O relego constituía-se no direito régio de venda do vinho em regime de monopólio, sem a concorrência de outros produtores. Normalmente esse período durava três meses, e variava entre o início de novembro ao princípio de fevereiro (Campos, 2010. p. 120).
} 
tiça e paz social. Desde seus congêneres gregos e romanos, ou legislando pelos souks islâmicos ${ }^{21} \mathrm{o}$ ato de almotaçar sempre implicou em garantir, igualitariamente, a oferta de gêneros e víveres que seriam destinados às feiras, mercados, lojas e vendas, mesmo que isto implicasse em racionamentos ou catalogação de valores. Justamente por se tratar de um ofício que vinculava-se diretamente à organização desses mercados, à distribuição de gêneros e víveres de máxima subsistência e que, de certo modo, regulava oferta e procura, este ofício nos parece primordial para a manutenção daquilo que se entendia como bem comum. ${ }^{22}$

Se é certo que as leis e o direito positivo fundamentaram-se em tradições e costumes oriundos de tempos imemoriais, estes, por sua vez, filiaram-se naturalmente à vivência cotidiana dos habitantes das cidades em suas atividades mais básicas e primordiais (Agamben, 2011). De acordo com Luiz Vidigal, desde o período medieval o direito local ou particular, estatuído para si pela própria comunidade nas assembleias comunais ou corporativas (concilia, juntae, capitula) era um direito que decorria, diretamente, dos sentimentos comunitários acerca do justo e do conveniente, um direito intensamente vivido e, geralmente, conhecido. Já as posturas traduziam lógicas próprias que os poderes centrais tentaram enquadrar (Vidigal, 1993, p. 106-107).

Entretanto, a religião também parece ter concorrido, fortemente, para estabelecer aquilo que se pautou como conveniente na vida em sociedade. Sem dúvida, a noção daquilo que era considerado justo esteve intimamente ligada aos dogmas e preceitos de religiões diversas, e certos comportamentos sociais parecem ter sido partiIhados e considerados desejáveis e, ao que tudo indica, são justamente esses sentimentos acerca do adequado em cada comunidade que passaram, paulatinamente, a compor um conjunto de regras e normas que balizaram o viver.

\footnotetext{
${ }^{21}$ Do árabe suque (ou suq), em espanhol zoco, ou em francês souq é termo que designa mercados tradicionais, zonas comerciais ou feiras periódicas (normalmente semanais) que ocorrem em países árabes e no norte da África. O termo equivalente em turco e persa é bazar. Já em amazigue, o idioma dos berberes é amenaz (lugar de venda). Normalmente estes mercados ocorrem ao ar livre, ou em centros históricos, as chamas almedinas. Da Andaluzia ao Irã, as funções primordiais de consumo e produção artesanal fizeram com que se criassem nas cidades ofícios diversos distribuídos em bairros e locais especializados. Nas imediações das grandes mesquitas formaram-se um conjunto de ruas de comércio e artesanato, normalmente estreitas e labirínticas, cada uma reservada aos representantes de um ofício. Na França e na Inglaterra verifica-se situação análoga, já que feiras e mercados cresciam de forma desordenada e transbordavam para ruas vizinhas, criando um mercado especializado. Recomenda-se: (Mantran, 1977, p. 236-237).

${ }^{22}$ Sobre a definição daquilo que se entendia por bem comum na Idade Média, veja: (Black, 1996).
} 
Uma incômoda herança da Antiguidade tardia parece ter sido a pobreza urbana. Ela teria sido ainda mais profunda e urgente do que as fraquezas dos humildes campesinos. Alguns trabalhos afirmam que desde o reinado do seu fundador, Constantinopla atraiu um grande número de desvalidos, tal qual teria ocorrido com Antioquia no tempo de Libânio, Éfeso, Cesaréia, Jerusalém e Alexandria (Mollat, 1989, p. 15-16). O enredo é típico: a precariedade de condições conduzia ao nomadismo, à vagabundagem e à miséria. No caso dos camponeses a falta de sementes foi, frequentemente, o ponto de partida para a penúria, além das intempéries, catástrofes e pilhagens.

Embora frágil, a estimativa de São João Crisóstomo daria conta de que 50 mil indigentes estariam em Constantinopla por volta do ano 400, algo manifestado à época como escandaloso e que provocava duas reações antagônicas, quais sejam, repressão e piedade. Alto funcionário do círculo do Constantino, Zótico teria empregado, clandestinamente, uma grande quantia para o resgate dos desvalidos e leprosos, a despeito da condenação imperial que, a bem da chamada salubridade pública, condenava-os à expulsão ou à morte. A existência desse leprosário fundado por Zótico às portas da capital, nas encostas da Gálata, foi denunciada a Constâncio. Zótico foi sumariamente condenado a ser arrastado e despedaçado por mulas. Mas arrependendose em seguida, o imperador transformou os alojamentos provisórios construídos pelo mártir num asilo permanente, batizado com o nome de sua vítima, e o renome de São Zótico difundiu-se de maneira durável por todo o império romano como o de um protetor dos pobres (Mollat, 1989). Desde a Antiguidade, o sentimento de solidariedade para com os desvalidos que se colocavam à margem das comunidades sempre esteve ligado a uma noção religiosa. Não raro, testemunhos sobre a vida dos santos e sermões variados traziam elementos de uma descrição das categorias de pobres e de suas condições de existência.

Ao menos para o caso romano, convinha garantir o abastecimento do povo e aquilo que, atualmente, denominamos como lazeres coletivos e qualidade de vida. Em Constantinopla, por volta do ano 321 as obras de assistência social já estavam sob a influência cristã, transformadas em instituições estabelecidas de modo irreversível. Segundo Michel Mollat, a autoridade imperial e a Igreja cooperavam mutuamente para ofertar ajuda aos desvalidos. Uma estava atenta para que os bens das igrejas e dos mosteiros, bem como as esmolas dos fiéis não fossem desviados de sua finalidade cari- 
tativa. A outra, assim encorajada, oferecia, como "serviço público" a esmola confiada às diaconias e o abrigo oferecido por uma rede de hospitais, já especializados nas cidades e nas estradas. Da generosidade antiga à caridade cristã é possível observar, assim, uma verdadeira continuidade na parte oriental do antigo mundo romano (Mollat, 1989, p. 17; Geremek, 1995b).

Foi decisivo para a Idade Média que, desde a Antiguidade tardia e os primeiros tempos medievais a concepção cristã da caridade, abrangendo a da pobreza, tenha sido proclamada e praticada por bispos e monges, no Oriente e no Ocidente. Esta concepção transformou a humildade espiritual num impulso para Deus, e visava aliviar a humilhação material e social dos pobres. Não obstante, o Concílio de Orleães em 511 determinava que os bispos dedicassem um quarto de seus rendimentos às necessidades dos pobres e, nas paróquias rurais, um terço das oferendas lhes ser destinado. Competia aos bispos exercer pessoalmente a misericórdia em relação aos desgraçados e estimular clérigos e laicos à caridade. Essas regras foram introduzidas no século VII nas novas dioceses fundadas na Germânia por São Bonifácio. Concílios francos, visigodos e italianos retornaram perpetuamente a estes temas, tanto que, por volta do ano 500 nada menos do que 41 concílios e sínodos preocuparam-se com os desvalidos. 0 bispo passou a ser, por assim dizer, o pai dos pobres e a sua casa tornou-se sinônimo de casa dos pobres. À sua porta, às vezes de suas próprias mãos, os pauperizados recebiam roupas e víveres (Mollat, 1989, p. 17-18).

Constatou-se a existência de listas de inscrição de pobres em Ravena entre 522 e 532. Em Roma, Gregório o Grande mandou atualizar um registro com a mesma serventia depositado no palácio pontificial. Continha os nomes dos homens e mulheres de todas as profissões, de Roma e suas cercanias, beneficiários das distribuições mensais de trigo, vinho, toucinho, peixe, azeite, queijo e legumes. Na Gália, a matrícula dos pobres foi assinalada desde antes de 470 em Reims, e em Laon a partir de 520. No século VI os matricularii estavam presentes em todas as aglomerações importantes. Em Metz, em meados do século VII, as matrículas das igrejas da cidade e das aglomerações vizinhas contavam 726 desafortunados, ${ }^{23}$ algumas mulheres, principalmente viúvas e, sobretudo homens, deficientes físicos ou doentes, considerados pobres válidos sem

\footnotetext{
${ }^{23}$ As matrículas devem ser vistas como valores aproximados, e não absolutos, tendo em vista que eram bastante variáveis.
} 
recursos ou vítimas de guerra, da fome ou da peste (Geremek, 1995a, Mollat, 1989, p. 41). Percebemos, portanto, que em períodos mais recuados cabia à Igreja garantir a sobrevivência dos menos favorecidos.

Contudo, com o desenrolar dos séculos o crescimento da pobreza, sobretudo urbana, parece ter exercido forte pressão para que as obras de misericórdia se associassem à intervenção das autoridades comunais. No século XIII já se prenuncia o controle dessas autoridades sobre o estabelecimento da gestão das instituições de assistência. Tal controle começou, ao que parece, pelos leprosários, por razões evidentes de salubridade pública. Nada mais lógico que ele tivesse se manifestado nas regiões de vida municipal mais precocemente desenvolvida. Como exemplo, os burgueses de Huy, na região de Liège participavam da gestão dos bens do leprosário. Em 1179, o bispo de Metz convocava a autoridade urbana a cumprir seu dever, nos seguintes termos: "O almotacel há de conservar inatos os direitos dos órfãos e das viúvas, tanto de pobres como de ricos" (Mollat, 1989, p. 99).

Ao que nos parece, na medida em que as lideranças locais iam se delineando de forma mais atuante, concomitante ao desenvolvimento urbano medieval, essa administração passou a assumir maiores responsabilidades, tanto com relação aos pobres quanto com relação às premissas básicas e desafios que o viver em cidades impunha. $\mathrm{A}$ dinastia de Avis e a revolução liderada por D. João I ainda em 1385 se colocaram como episódios significativos para o estudo das leis e de todo o corpus administrativo que regeu os reinos de Portugal e Espanha e, posteriormente, suas conquistas de ultramar no início da época Moderna. A partir daquele momento se percebeu a necessidade de uma codificação que se fizesse ampla e presente, afirmando o poder régio e, mais tarde, contribuindo para a formação e o fortalecimento das monarquias nacionais.

Se analisarmos os regimentos dos almotacés da cidade de Évora, veremos que tais documentos foram sendo compilados, ampliados, modernizados e finalmente incorporados às Ordenações Afonsinas, que datam de 1446, o que fez com que este estatuto atingisse também, posteriormente, através das recopilações Manuelinas e Filipinas, os domínios ultramarinos portugueses, constituindo um corpo legal de referência. ${ }^{24} \mathrm{O}$ regimento que segue é parte integrante do foral da cidade nos tempos de D.

\footnotetext{
${ }^{24}$ Entretanto, somente com a promulgação das Ordenações Filipinas, recopiladas por ordem dos reis Felipe III de Espanha e Felipe I de Portugal em 1603, que constituíram o mais bem feito e duradouro
} 
João I, ${ }^{25}$ e descreve as funções dos almotacés que atuavam no Termo:

(...) "It. os almotacés sejam bem avisados que ao primeiro ou até o segundo dia como entrarem a mais tardar mandem logo apregoar que os carniceiros e padeiras e regateiras e almocreves e alfaiates e sapateiros e todo os outros mestres usem cada um de seus mestres e dêem os mantimentos aavondo guardando as vereações e posturas do concelho e outros e todos os que têm medidas de pão e vinho e azeite que as mostrem para as verem se são direitas sob a pena que Ihe é posta na postura do concelho." ${ }^{26}$

A seguir temos um segundo trecho em que notamos a clara semelhança com o regimento dos almotacés de Évora. Trata-se da introdução das atribuições dos juízes almotacés descritas nas Ordenações Filipinas:

"Os almotacés terão cuidado, que o primeiro até o segundo dia, a
mais tardar como entrarem, mandem logo pregoar que, os Carnicei-
ros, Padeiras, Regateiras, Almocreves, Alfaiates, Sapateiros, e todos
os outros oficiais usem de seus ofícios e dêem mantimentos em abas-
tança, guardando as Vereações e posturas do Concelho". ${ }^{27}$

Não obstante este trecho introdutório, ao longo das Ordenações Filipinas notamos outras semelhanças com o regimento que vigorava em Évora, como explicita o trecho a seguir que versa sobre a taxação do pescado colocado à venda nos mercados, que apesar da diferença entre a grafia e o texto, aqui modernizado, guardam íntima semelhança:

(...) "It. os almotacés sejam bem avisados e diligentes em seus ofícios e aos dias que o pescado vier cheguem logo a praça e ponham em ela almotaçaria segundo seu costume pondo o maior e meãao e mais pequeno segundo sua valia pondo as mostras em lugar onde as vejam os que o comprarem. E se o pescado for pouco estejam e ambos ou um deles que o repartam pelos os maiores e menores cada hum como o merecer segundo o pescado for em tal guisa que os ricos e

código legal Ibérico, é que podemos assegurar a expansão e efetiva aplicação da legislação oficial. Ver: (LARA, 1999, p. 22).

${ }^{25}$ D. João I foi um dos monarcas que mais se dedicou a sanar as divergências entre as diversas medidas e pesos em vigor no reino português, publicando diversas provisões voltadas diretamente ao direito de almotaçaria, como a lei de 1488 que adotava o marco de colônia como peso padrão a ser utilizado nas transações comerciais.

${ }^{26}$ REGIMENTO da cidade de Évora feito por João Mendes no tempo de D. João I (Pereira, 1998. p. 147177).

${ }^{27}$ ORDENAÇÕES Filipinas. Livro 1, Título LXVII. p. 157. 
pobres ajam todos mantimento e não se partam até que seja dado e repartido como dito é. ${ }^{28}$

Acima temos parte integrante do foral de Évora, e abaixo, uma derivação que consta no texto das Ordenações Filipinas:

\begin{abstract}
"Item, os Almotacés serão diligentes em seus ofícios, e os dias que o pescado vier, irão a praça, e ponham nele a almotaçaria, segundo o seu costume, pondo o maior, e o meão, e o mais pequeno, segundo a sua valia, e pondo as mostras em lugar onde as vejam os que comprarem. E se o pescado for pouco, estejam aí ambos, ou um deles, que o reparta, segundo o pescado for, de maneira que os ricos e pobres hajam todos mantimento. E não se vão daí, até que seja todo repartido". ${ }^{29}$
\end{abstract}

As comparações tornam-se válidas, pois considerando os regimentos de Évora, notamos que estas posturas foram sendo utilizadas visando conceder maior legitimidade pautada nos costumes e tradições administrativas exercidas nas cidades da península Ibérica, tradições estas que vão ao encontro dos antigos dogmas religiosos acerca do justo, e da preocupação da Igreja com relação aos desvalidos, garantindo aquilo que chamamos de bem comum. Com a centralização administrativa promovida pelos reis em fins da Idade Média, a preocupação com a manutenção do bem comum assumiu, pouco a pouco, importância capital na agenda política, ao mesmo tempo em que a Igreja foi cedendo a primazia na condução de boa parte das questões urbanas que, a partir de então, foram sendo vistas sob ótica administrava, e não mais estritamente religiosa.

À guisa de conclusão, percebemos que a almotaçaria exercida durante séculos na península Ibérica foi ofício diretamente responsável por atribuições significativas em seio citadino, e pode ser vista através de uma longa linha de filiação que aponta, também, para a caridade e a assistência aos desassistidos e marginalizados. Algumas de suas atribuições, como a garantia de abastecimento e distribuição de víveres e artigos de primeira necessidade aos mais necessitados foram agendas que perduraram e fizeram deste cargo uma longeva instituição, que perdurou por mais de setecentos

\footnotetext{
${ }^{28}$ REGIMENTO da cidade de Évora feito por João Mendes no tempo de D. João I (Pereira, 1998, p. 147177).

${ }^{29}$ ORDENAÇÕES Filipinas. Livro 1, Título LXVIII, p. 158.
} 
anos, somente no reino cristão de Portugal. Ao fim e ao cabo, percebemos que a religião e alguns de seus preceitos parecem ter concorrido para gerar construtos políticos e administrativos solidificados e postos em prática nos núcleos urbanos com o alvorecer da Modernidade, ficando tácito que a história religiosa e a história política caminharam lado a lado, moldando as bases da sociedade que se desenhou naquele período.

\section{Obras de referência:}

BLUTEAU, R. Vocabulário Portuguêz \& Latino, aulico, anatomico, architectonico... Coimbra: Colégio das Artes da Companhia de Jesus. 1728.

CARRERA, Vicenç Joaquín Bastús i. Diccionario Histórico Enciclopédico: Barcelona, 1828. p. 44.

HACHETTE, Chez L. Dictionnaire Universel D’Histoire et de Géographie. Paris: Libraire de L'Université. 1842. p. 540.

PEREIRA, G. 1998. Documentos Históricos da Cidade de Évora. Imprensa Nacional da Casa da Moeda, Lisboa, 1998. p. 147-177.

TORRES, R. A. 1992. Dicionário de História de Portugal. Porto: Livraria Figueirinhas. 1992. v.4. p. 121.

\section{REFERÊNCIAS}

AGAMBEN, G. 2011. O Reino e a Glória: uma genealogia teológica da economia e do governo, Boitempo, São Paulo, 326 p.

BEIRANTE, A. M. R. 1995. Évora na Idade Média. Lisboa: Fundação Calouste Gulbenkian/JNICT, Lisboa, 679 p.

BICALHO, M. F. 1998. As Câmaras Municipais no império português: o exemplo do Rio de Janeiro. In: Revista Brasileira de História. (Vol. 18, no 36), p. 43-93.

BLACK, A. 1996. El Pensamiento Político em Europa (1250-1450). Cambridge University Press, Cambridge, $338 \mathrm{p}$.

BOURDIER, P. 1989. O Poder Simbólico. Bertrand, Lisboa, 468 p.

BOXER, C. R. O Império Marítimo Português. 1415-1825. Companhia das Letras, São Paulo, $572 \mathrm{p}$.

CAETANO, M. 1991. A Administração Municipal de Lisboa durante a primeira dinastia (1179-1383). Livros Horizonte, Lisboa, 346 p.

CAMPOS, M. A. 2010. Alimentar a cidade de Coimbra na Baixa Idade Média: notas sobre os alimentos, as estruturas de transformação alimentar e os ofícios. In: SOARES, C. e MACEDO, I. C. (Coords). Ensaios sobre Património Alimentar Luso-Brasileiro. Coimbra: Imprensa da Universidade de Coimbra. p. 113-137.

CAPELA, J. V. Administração local e municipal portuguesa do século XVIII às reformas liberais: alguns tópicos da sua historiografia e nova história. In: CUNHA, M. S. e FON- 
SECA, T. (Orgs.) 2005. Os Municípios no Portugal Moderno: dos foros manuelinos às reformas liberais. Edições Colibri CIDEUS/EU, Évora, 39-58 p.

COLOM, F. S. 1953. De la institución del mustaçaf de Barcelona, de Majorca y de Valência. In: Anuário de História del Derecho Español. (no XXIII, t.23), p. 525-538.

GEREMEK, B. 1995. A piedade e a forca: história da miséria e da caridade na Europa. Terramar, Lisboa, $306 \mathrm{p}$.

GEREMEK, B. 1995. Os Filhos de Caim: vagabundos e miseráveis na literatura europeia (1400-1700). Companhia das Letras, São Paulo, 402 p.

LARA, S. H. (org.) 1999. Ordenações Filipinas, Livro V. Companhia das Letras, São Paulo, $510 \mathrm{p}$.

LOBO, E. M. L. 1975. O Comércio Atlântico e a comunidade de mercadores no Rio de Janeiro e em Charleston no século XVIII. In: Revista de História. (Vol. LI, no 101), p. 49106.

MANTRAN, Robert. A Expansão Muçulmana. (séculos VII-XI). Pioneira, São Paulo, 266 p.

MOLLAT, M. 1989. Os pobres da Idade Média. Campus, Rio de Janeiro, 183 p.

MONTEIRO, Nuno Gonçalo. "Os Conselhos e as Comunidades." In: MATOSO, José. (org.) História de Portugal: quarto volume, o Antigo Regime (1620-1807). Lisboa: Editorial Estampa, 1983. p. 304-309.

MONTSERRAT, B. 1993. Aspectes del comerç a Catalunya em el segle XVI segons els llibres dels mostassas. Universitat de Lleida, Lleida, 394 p.

PEREIRA, M. R. M. 2001. Almuthasib - Considerações sobre o direito de almotaçaria nas cidades de Portugal e suas colônias. In: Revista Brasileira de História (Vol. 21-no 42), p. 365-395.

PIRES, M. C. 2005. Em Testemunho de Verdade: juízes de vintena e o poder local na Comarca de Vila Rica (1736-1808). Belo Horizonte. MG. Tese de Doutoramento. Universidade Federal de Minas Gerais, 436 p.

RUBIO, J. H. E. 2012. San Pablo, Jesucristo Y El Cristianismo. Palibrio, Bloomignton, 342 p.

RUSSEL-WOOD, A. J. 1981. Fidalgos e Filantropos: A Santa Casa da Misericórdia da Bahia, 1550-1755. Editora da UNB, Brasília, 479 p.

SALGADO, G. 1986. Fiscais e Meirinhos: a administração no Brasil Colonial. Nova Fronteira, Rio de Janeiro, $452 \mathrm{p}$.

$\mathrm{SCHACHT}$, J. 1995. Esquisse d'Une Histoire du Droit Musulman. Besson, Paris, 436 p.

THOMAZ, L. F. 1998. De Ceuta a Timor. Difel, Lisboa, 780 p.

VIDIGAL, L. 1993. Câmara, Nobreza e Povo: poder e sociedade em Vila Nova de Portimão (1755-1834). Câmara Municipal de Portimão, Portimão.

WEHLING, A. e WEHLING, M. J. 2000. O funcionário colonial entre a sombra e o rei. In: DEL PRIORE, M. (org). Revisão do Paraíso: os brasileiros e o Estado em 500 anos de história. Campus, Rio de Janeiro, 366 p. 